\author{
Fırat University, esratugruldfirat.edu.tr, Elazığ-Turkey
}

\begin{tabular}{l|l|l}
\hline DOI & http://dx.doi.org/10.12739/NWSA.2018.13.2.E0042 \\
\hline ORCID ID & $0000-0001-9071-774 \mathrm{X}$ \\
\hline
\end{tabular}

\title{
INVESTIGATION OF THE ABRASION RESISTANCE OF THE QUARTZITIC NATURAL AGGREGATE FOR DIFFERENT TEST PARAMETERS
}

\begin{abstract}
Turkey has many types of aggregates that have different chemical and physical properties. Waste aggregates or low-cost aggregates must be evaluated in the industry to benefit the environment. Turkey has large water reserves. Therefore, the usability of natural aggregates, created by the sweeping of water in places like river beds, lakes, and coasts, in industrial areas such as construction and metallurgy should be investigated. Because these aggregates have a quartzitic characteristic, it is also believed that their strength will be high. In this study investigates the abrasion resistance of natural aggregates with quartzite characteristics obtained from river beds in the Mediterranean Region. This study aims to investigate the usability of these natural aggregates in concrete. For the usability of these quartzitic natural aggregates in concrete, it has been investigated whether they have the appropriate abrasion value conforming the relevant Turkish standard. Thus, it is aimed to provide both an environmentally friendly production and economic gain. The present study was carried out experimentally using the Los Angeles test device for different test parameters. From this study, it has been concluded that these natural aggregates can be used for the production of concrete which has sufficient strength especially in terms of abrasion resistance. The abrasion resistance of the aforementioned aggregates was compared with the abrasion resistance of aggregates with different properties used in previous studies.
\end{abstract}

Keywords: Abrasion Resistance, Quartzitic, Natural Aggregate, Los Angeles, Concrete

\section{INTRODUCTION}

Concrete is the most important building material used today in terms of being resistant to the loads, long service life and easy and cheap production. Factors such as the properties of concrete constituents, mixing ratios, and proper mixing and placement of concrete directly affect the concrete quality. In addition, aggregate, which is one of the concrete components, is one of the parameters that affect most the quality of concrete. The properties of the aggregate used must be determined by laboratory studies in order to determine the concrete quality. Aggregates, which constitute about 60\%-80\% of the concrete volume and are the granular materials such as sand, gravel, and crushed stone, form the main structure of the concrete [1]. The aggregates to be used in concrete must have some important properties as they have a significant effect on the properties of the concrete of which they are a constituent. Aggregates to be used in concrete production must comply with the TS 706. However, aggregates to be used in concrete must be hard, strong, durable, without gaps and should not soften and dissipate under the influence of water. They must be resistant to pressure and abrasion 
and should not contain materials such as clay, schist, and flat, long and weak grains [2]. Aggregates should not form harmful compounds with cement components and should not endanger the protection of the reinforcement against corrosion. Grains should have good shape and texture. The distribution of the grains in terms of size must comply with the intended use and the relevant standards. There must be no harmful substances in the grains [3].

Natural aggregates are the ones obtained from places like river beds, coasts, streams, glaciers, and deserts. Among these, aggregate quarries in river beds are the most common and preferred sources. Because these aggregates are economical as they can be used without being subjected to any treatment. The grains are generally round in shape. As they are in contact with water, they have been exposed to adequate abrasion and therefore soft and weak grains have been sieved. As a result of the abrasion caused by dragging, hard, solid and durable grains remain. The best natural aggregates are obtained from streams. These aggregates consist of clean and smooth grains. Since they have a high compensation, they affect the concrete strength positively [4]. Poitevin (1999) emphasized that the Los Angeles abrasion resistance was one of the most important criteria for the usability of aggregates in concrete. However, it is reported that detailed and systematic investigations are needed due to the hazard of alkaline-aggregate reaction. It is also reported that high-resistant concrete can be obtained if aggregates with low water absorption value are used [5].

Especially the concrete in roads and airfields are under the influence of impact and abrasion. The coarse aggregate used to protect the concrete from these effects must be resistant to abrasion. According to TS 706, if the compressive strength of the aggregate is less than $9806.65 \mathrm{MPa}$, the abrasion resistance of the aggregate is suspected, or if any artificial aggregate is used in the making of concrete, then the abrasion resistance of the relevant aggregate must be determined by tests. According to TS EN 1097-2, the standard abrasion resistance test is carried out for 12 balls and 500 revolutions. This measured value is determined as 10\% for the maximum 100 revolutions and as 50\% for 500 revolutions according to the TS 706 abrasion limit values. The concrete that contains aggregates with high abrasion resistance has a high compressive strength [6].

In the study by Temiz, et al., (2006), the properties of natural aggregates used for the production of concrete in Kahramanmaraş and Gaziantep provinces were investigated. It was seen that the abrasion resistance of the aforementioned aggregates was below the limit values stipulated by the standard. Therefore, it was concluded that these can be used as the concrete aggregates, especially as the road concrete and bitumen concrete aggregates. However, it was seen that these aggregates contained substances that could damage the concrete and therefore should not be used without being washed [7].

In the study by Alyamaç and Tuğrul (2014) the abrasion resistance of marble and limestone aggregates of a particular region were compared. It was stated that these aggregate types could be used in concrete because Los Angeles abrasion values were below the limit value in accordance with the standards [8].

In the study by Tuğrul (2017), the abrasion resistance of marble aggregates was investigated for different Los Angeles parameters. The effects of the parameters such as the number of balls and revolutions particular to the test device on the abrasion resistance were investigated. It was concluded that the said aggregate could be used in concrete [9]. Similarly, in the study by Tunç (2018), the abrasion resistance of the basalt aggregate, which is thought to be high due to its chemical content, was investigated under different Los Angeles 
parameters. It was concluded that the high quality and performance concrete can be obtained with the said basalt aggregate [10].

The present study aims to investigate the abrasion resistance of the natural aggregates obtained from a river bed through the Los Angeles abrasion test for different test parameters. Because it is thought that the aggregates obtained from a river bed will have both quartzitic properties and have high abrasion resistance due to the fact that they are purified from the materials with low strength with the effect of water. It is planned to produce high strength concrete with the use of these aggregates with high abrasion resistance in concrete.

\section{RESEARCH SIGNIFICANCE}

As is known, the aggregate is one of the most important factors affecting the strength of concrete. Aggregate directly affects many properties of concrete, such as workability, resistance, and permeability. It is necessary to determine the properties of the aggregate to be used in order to obtain the desired performance from the concrete according to the place of use [11]. In addition, the fracture of aggregate and the removal of adherence are the most important factors that cause damage to the concrete [12]. It is not possible to produce suitable concrete with the aggregates which are used before their properties are determined. Thus, both unnecessary materials will be used, and unnecessary work will be done because the aggregate potential is not fully known. This prevents efficient and economic production. In environments that are forced under dynamic loads, aggregates are of great importance in terms of the abrasion of concrete. In this respect, it is desired that the concrete used under conditions where the concrete surface is exposed to abrasion, should be made with abrasion resistant aggregates. In Tunç (2019) was stated that the strength characteristics of aggregates, especially in waste situations, can be investigated and if they can be used in the concrete, a great gain can be made in terms of environment and economy [13]. In this experimental study, it is aimed to ensure the production of durable concrete by determining the abrasion resistance of aggregates to be used. Thus, with this study, it is planned to present useful information to the literature and application engineers about the usability of natural aggregates in concrete and their effects on the concrete strength.

\section{PROPERTIES OF QUARTZITIC NATURAL AGGREGATES}

Quartz is usually a light colored and fine-grained mineral. Quartz contains 53.3\% of $\mathrm{O}$ and $46.5 \%$ of $\mathrm{Si}$ elements and its chemical formula is $\mathrm{SiO}_{2}$. The hardness of this mineral on the Mohs scale is 7 , its specific gravity is $2.65 \mathrm{kN} / \mathrm{m}^{3}$, and its melting temperature is $1785^{\circ} \mathrm{C}$. It is a mineral that is abundant in nature. There are major elements such as Li, $\mathrm{Na}, \mathrm{Al}, \mathrm{Ti}$ and $\mathrm{Mg}$ in quartz in the solid-melt form [14]. The high-quality quartz is preferred particularly in industrial applications. Brazil has the largest high-quality quartz reserves on Earth. The world's most natural and purest quartz reserves are found in the USA, Namibia, Angola, Madagascar, China, and India [15]. Turkey has approximately 6.3 billion tons of quartzite reserves, while its quartz sand potential is around 65 million tons. The $\mathrm{Fe}_{2} \mathrm{O}_{3}$ content of quartz sand reserves in Turkey ranges from $0.11 \%$ to $0.95 \%$ [14]. The quartz reserves in Turkey are mostly located in Antalya, Zonguldak, Kastamonu, Istanbul, Aydin, Izmir, Adana, Istanbul and Denizli provinces [16]. A view of the quartzite aggregate quarries in Turkey is presented in Figure 1. Quartzites are used for various purposes in the refractory (silica brick), metallurgy (iron and ferrochrome), construction (production of lightweight gas concrete construction elements) industry, and glass and ceramics industry. 


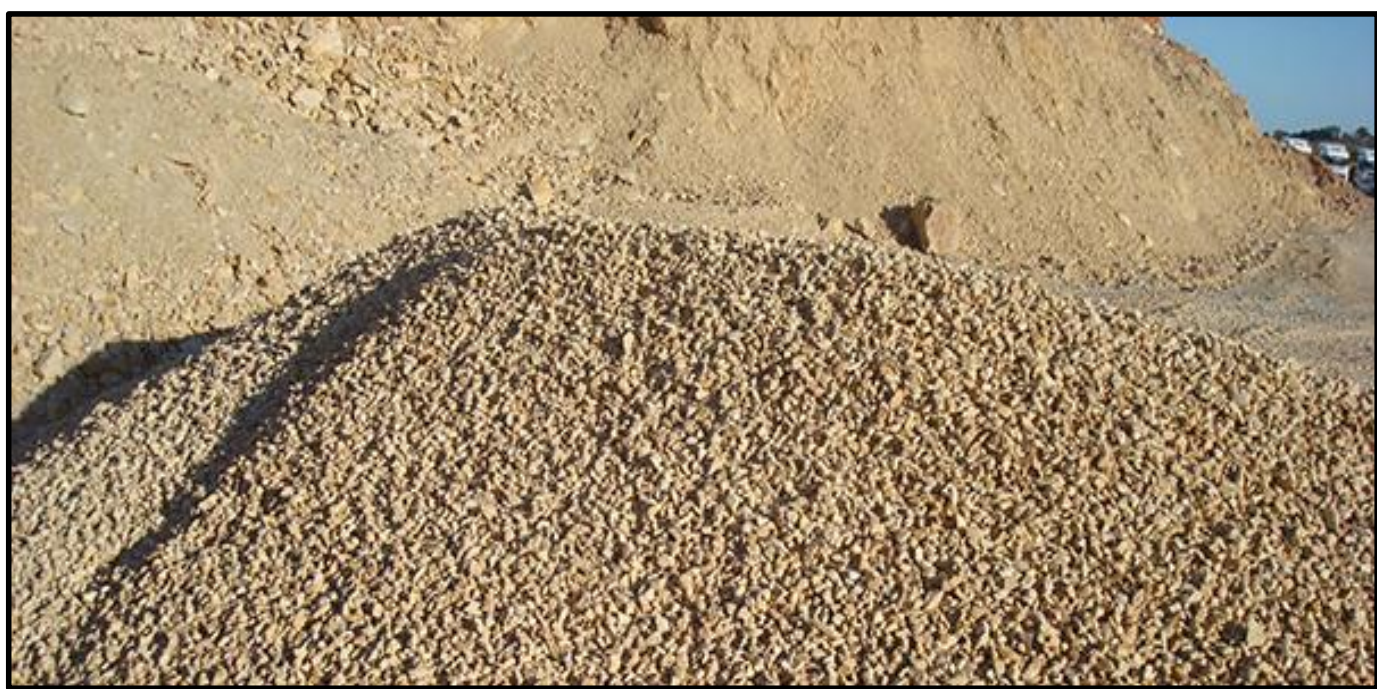

Figure 1. A view from the quarzitic aggregate quarry [24]

\section{EXPERIMENTAL STUDY}

The quartzite natural aggregate type obtained from the river beds of the Mediterranean region was used in the present experimental study (Figure 2). The tests were performed in Elazığ, Fırat University, Engineering Faculty, Civil Engineering Building Materials Laboratory.

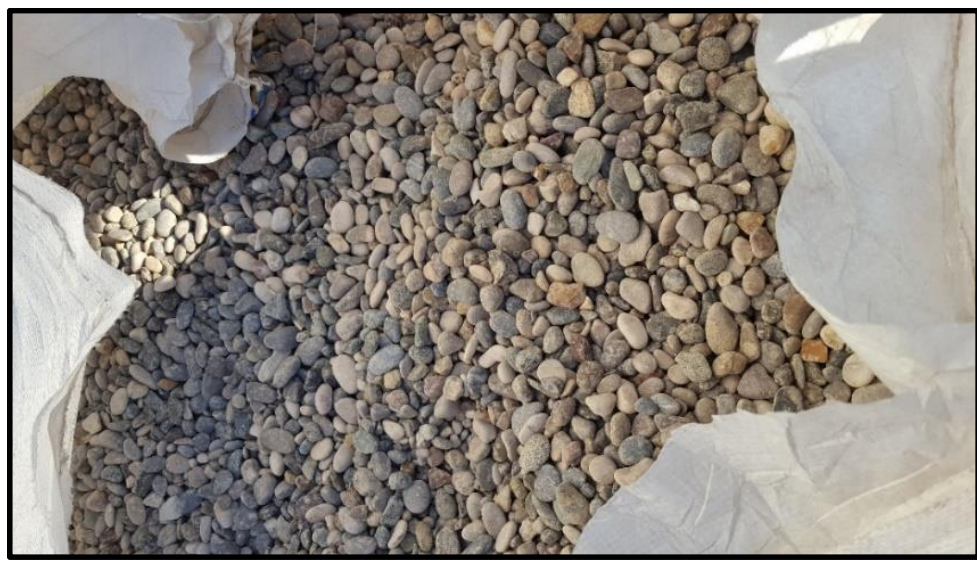

Figure 2. Natural aggregates from river beds in the Mediterranean Region

The specific weight of the saturated dry surface for the coarse aggregate used in the present experimental study was determined as $S_{d y k}{ }^{\text {coarse }}=2.60 \mathrm{~g} / \mathrm{cm}^{3}$ and the water absorption rate for the coarse aggregate was $S_{a}$ coarse $=0.47 \%$. The granulometry curve of natural aggregates with the largest grain diameter of $16 \mathrm{~mm}$ is presented in Figure 3 . Attention should be paid to maximum compactness in the granulometric distribution. Because the concrete produced with aggregate having maximum compactness requires less cement and has a high compressive strength. In addition, it is known that the natural aggregates with the highest compactness are the ones that are obtained from river beds. Because these aggregates are composed of clean and uniform grains. Thus, it is obvious that these aggregates will have positive effects on the concrete strength. In Figure 3, the maximum compactness is provided because, according to the TS802 [17], the aggregate granulometry curve is mostly between the $A_{16}-B_{16}$ standard curves. 


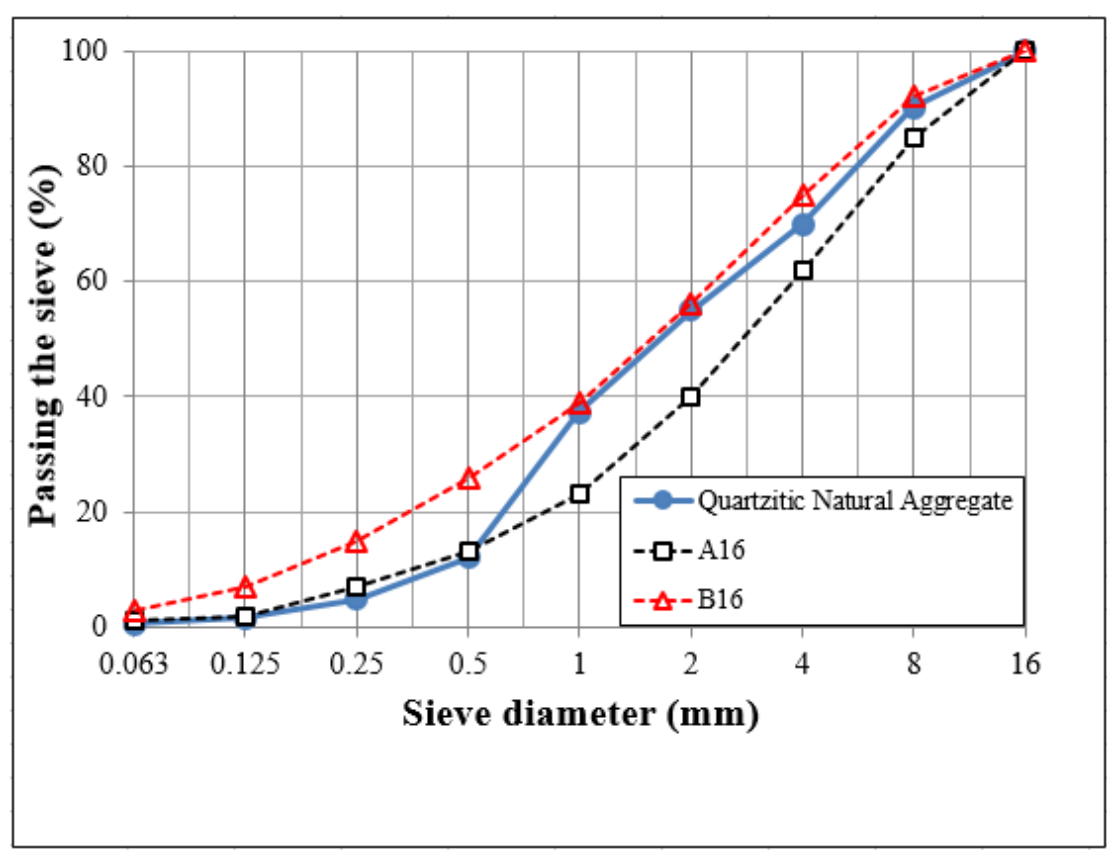

Figure 3. The granulometry curve of quartzitic natural aggregates

The Los Angeles abrasion test is performed to measure the resistance of the aggregate to impact abrasion. The Los Angeles abrasion test is performed according to TS EN 1097-2 [18] in order to determine the strength and abrasion resistance of the aggregates. The Los Angeles test is a method used to determine the percentage of material remaining on a certain sieve aperture as a result of rotating the coarse aggregates with steel balls in Figure $4 \mathrm{a}$ in a drum. It is accepted that the lower the Los Angeles abrasion value, the higher the resistance of the grains to mechanical effects. In order to use the relevant aggregates as concrete aggregates, the Los Angeles abrasion value should be less than 50\% [19]. The Los Angeles test device in Figure 4b was used for the test. This device consists of an electric motor, a revolution counter, an automatic circuit switch that stops the operation of the electric motor at the end of the predetermined number of revolutions and a hollow steel cylinder with two ends closed. The inner diameter of the drum is $70 \pm 0.5 \mathrm{~cm}$, its inner length is $50 \pm 0.5 \mathrm{~cm}$ and it was embedded in a way to rotate around its axis in the length direction. The lid of the drum can be tightly closed so that no dust can be emitted. 


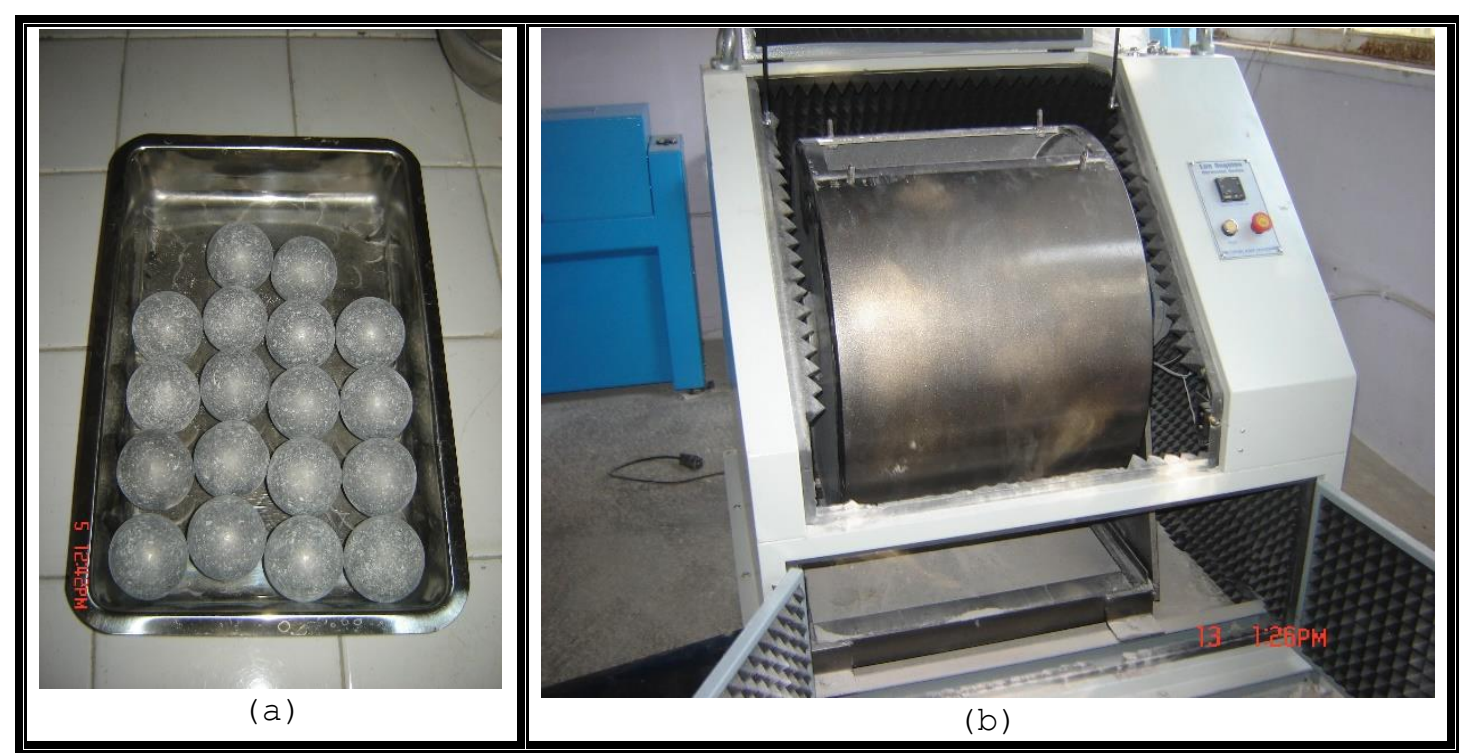

Figure 4. a) Steel balls used in the test b) Los Angeles test device

For the test, a total of $5000 \mathrm{~g}$ sample was washed, including $2500 \mathrm{~g}$ of the material remaining between 8-16 mm mesh sieves, and $2500 \mathrm{~g}$ of the material remaining between $4-8 \mathrm{~mm}$ mesh sieve according to the TS706. Then, these materials were weight after being dried in the drying-oven with a temperature of $110 \pm 5^{\circ} \mathrm{C}$ until it becomes constant $\left(G_{1}\right)$. The balls and the dried samples were put to the drum that rotated at a constant speed of 31-33rpm and the lid was closed and the drum was rotated at $500 \mathrm{rpm}$. The aggregates and balls were poured into the tray at the end of the test. The balls were cleaned from the samples being attentive to not to cause any loss of sample. Samples were sieved on a $1.4 \mathrm{~mm}$ mesh screen and those remaining on the sieve were weighed $\left(G_{2}\right)$. Finally, the Los Angeles abrasion rate is calculated using Equation (1) in accordance with the TS EN 1097-2.

$$
L A\left(\frac{\circ}{0}\right)=\frac{G_{1}-G_{2}}{G_{1}} \times 100
$$

After the weighing process, the aggregates, which were put to the drum again with balls, were rotated at 500 rpm. Thus, aggregates were subjected to a total of 1000 revolutions of abrasion. After this operation, the LA (\%) value was calculated again for 1000 revolutions. Similarly, the LA (\%) values of the aggregate sample poured into the drum were found separately at the end of 1500 and 2000 revolutions. This test process was repeated using 12,18 and 24 balls.

\section{RESULTS AND DISCUSSION}

In this experimental study, a series of tests were performed by changing the parameters of the Los Angeles abrasion test device such as the numbers of balls and revolutions. The effects of these parameters on the LA ( $\left.\frac{0}{0}\right)$ coefficient, i.e. the aggregate abrasion, were investigated. In the tests performed for 12, 18 and 24 balls, it was observed that the LA abrasion value increased, and the abrasion resistance decreased with the increasing number of revolutions. The LA value increased linearly with the increase in the number of revolutions. In the test performed for the maximum number of revolutions and balls, it was concluded that the LA value was almost $100 \%$, i.e. the material had no resistance to abrasion. Therefore, it was determined that the abrasion value of the aforementioned aggregate was below the standard limit in the tests performed for 12 balls/500 revolutions, 18 balls/500 revolutions, 24 balls/500 revolutions, and 12 balls/1000 revolutions. It was seen that 
the abrasion resistance of the aggregate yielded results that do not conform to the standard under other conditions. The average increase in the LA abrasion value was $76.8 \%$ when the number of revolutions increased from 500 to $1000,28.5 \%$ from 1000 to 1500 revolutions, and 13\% from 1500 to 2000 revolutions. It was seen that the rate of increase in LA was highest in the transition from 500 to 1000 revolutions. As the number of revolutions increased, the rate of increase in LA decreased as the LA abrasion value approached the maximum level (Figure 5).

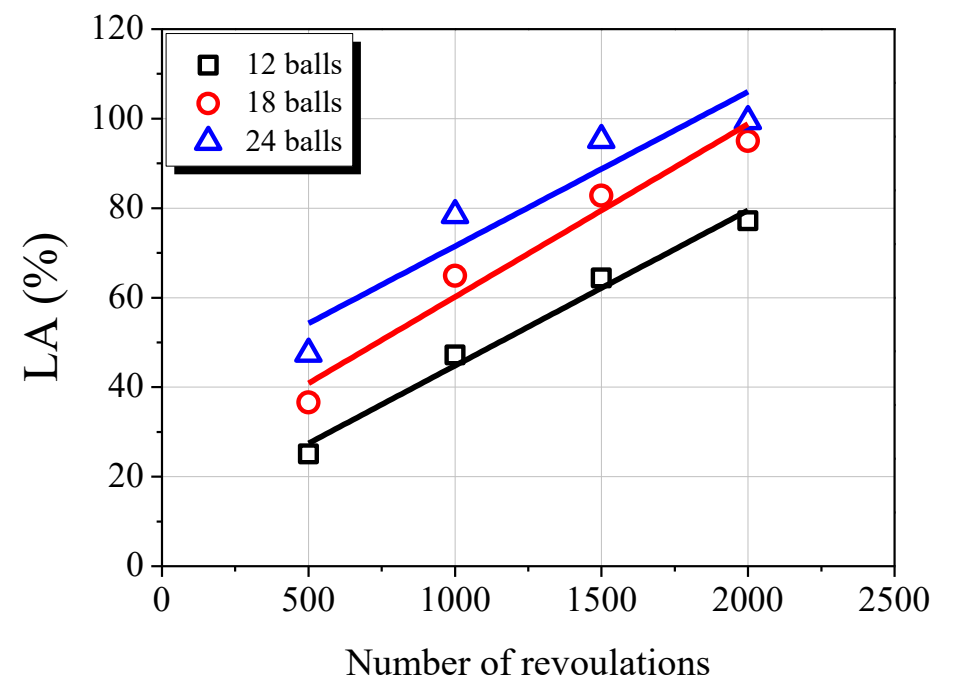

Figure 5. Variation of LA abrasion value with the number of revolutions for 12 balls, 18 balls, and 24 balls

In Figure 6, it was seen in the tests performed for 500, 1000, 1500 and 2000 revolutions that as the number of balls increased, the LA abrasion rate increased, and the abrasion resistance decreased. The LA value increased linearly with the increase in the number of balls. An average increase of $33.7 \%$ was seen in the LA abrasion value when the number of balls was increased from 12 to 18 , and of $17.5 \%$ when the number of balls was increased from 18 to 24. It was determined that the change in the number of revolutions affects the LA abrasion value and hence the abrasion resistance of the aggregate. 


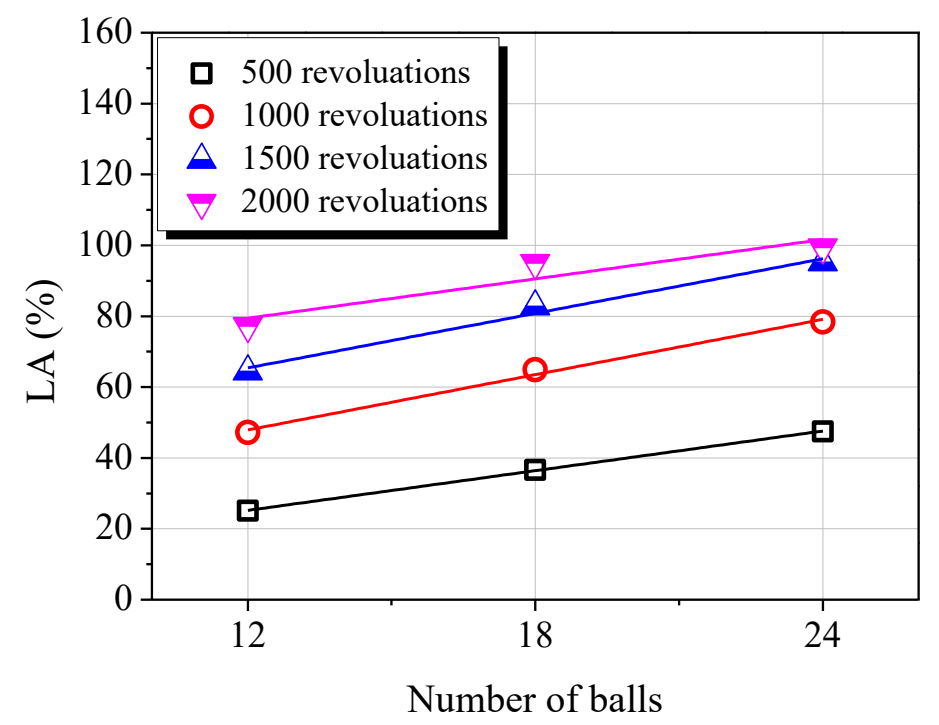

Figure 6. Variation of LA abrasion value with the number of balls for 500 revolutions, 1000 revolutions, 1500 revolutions, and 2000

revolutions

\section{COMPARISON OF THE RESULTS OF THE PRESENT STUDY AND RESULTS OF THE PREVIOUS STUDIES}

In Figure 7, the abrasion value of the quartzite natural aggregate used in the present study and the abrasion values of the aggregate types used in similar studies in the literature were compared. Accordingly, it was concluded that the LA abrasion value of the natural quartzite aggregate was lower than the LA abrasion values of most of the aggregate types in the literature and therefore it is more resistant to abrasion.

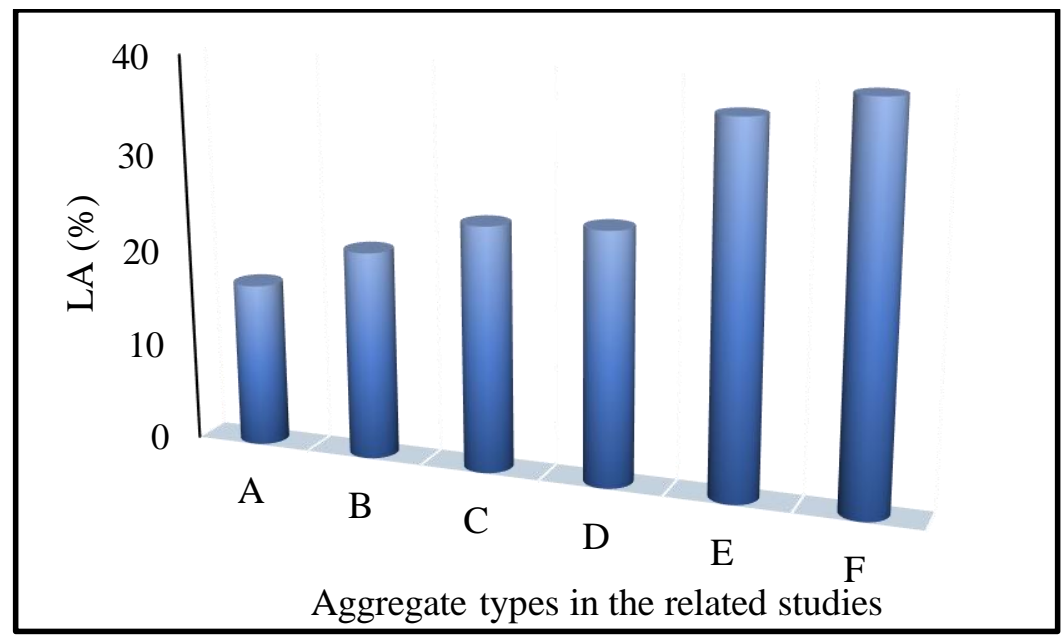

Figure 7. Comparison of the abrasion values of the quarzitic natural aggregate used in the present study and the aggregate types in the literature

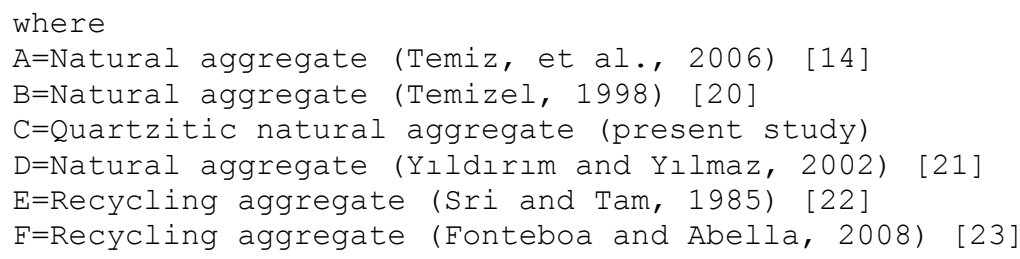


In Figure 8, the LA abrasion value of the quartzite natural aggregate used in the present study was compared with the LA abrasion values of the marble and basalt aggregates studied in the literature according to the changing numbers of balls. As is known, the basalt aggregate is one of the most rigid and strong aggregates found in nature. Nevertheless, the abrasion value of the present natural aggregate was not much higher than that of the basalt aggregate and was lower than the marble aggregate. This shows that the abrasion resistance of the present natural aggregate is lower than that of basalt and higher than that of marble.

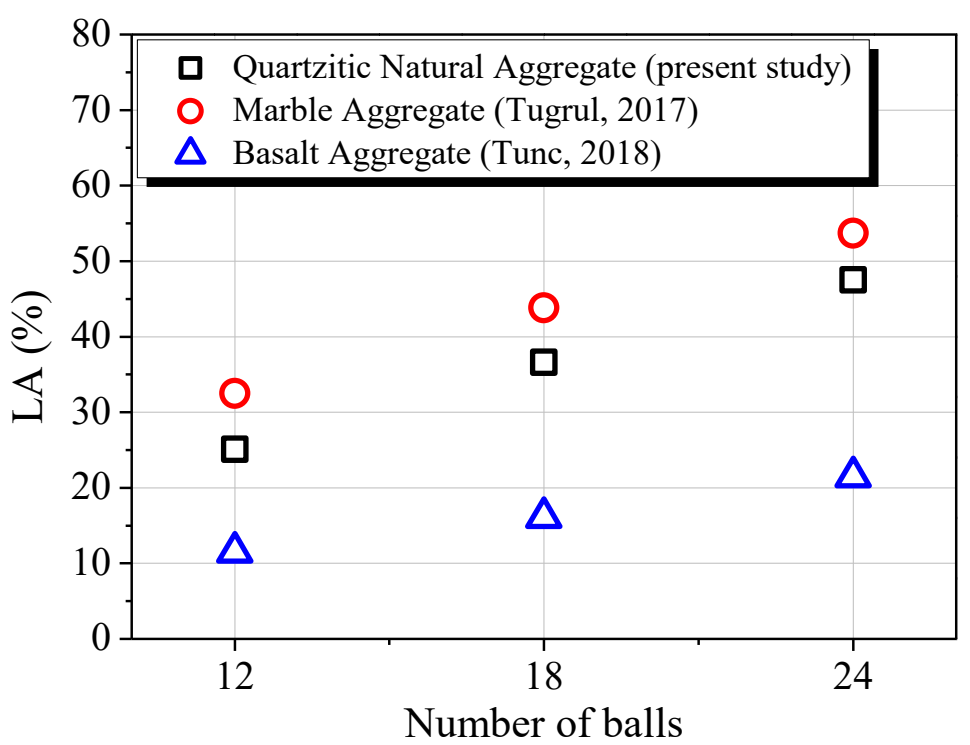

Figure 8. Comparison of the LA abrasion values of the present quarzitic natural aggregate type and the marble and basalt aggregates in previous studies

\section{CONCLUSIONS}

The conclusions of the present study are summarized below:

- Abrasion has a great effect on concrete strength. Because the aggregates with high abrasion resistance have a high compressive strength and the concrete produced with aggregates with high abrasion resistance have higher values of compressive and bending strengths.

- As a result of the test performed for 12 balls and 500 revolutions according to the TS 706, the LA abrasion value is $25.1 \%$ and the limit value is quite less than 50\%. Therefore, it has been determined that the present quartzitic natural aggregates are resistant enough to abrasion and can be used safely in concrete.

- A significant reduction was seen in the abrasion resistance with the increasing number of balls and revolutions, which are the parameters of the Los Angeles test device.

- The LA wear value has increased continuously and linearly with the increase in the number of balls and revolutions.

- In the test performed for the case where the numbers of revolutions and balls are at the maximum level, it was concluded that the LA value was almost $100 \%$, i.e. there was no resistance against abrasion. 
- As the number of revolutions increased, the rate of increase in LA decreased as the LA abrasion value approached the maximum level.

- It has been determined that the change in the number of revolutions affects the LA abrasion value and therefore the abrasion resistance of the aggregate.

\section{REFERENCES}

[1] Güner, M.S., (1999). Material Science-Building Materials and Concrete Technology. Bakanlar Medya, İstanbul, 18-65 (in Turkish).

[2] Kamanlı, M. and Balık, F.S., (2003). Concrete Technology. Atlas Yayıncllık, İstanbul, 13-35 (in Turkish).

[3] Simsek, O., (2000). Building Materials Cilt II. Ankara Üniversitesi Basımevi, Ankara, 26-58 (in Turkish).

[4] Güner, M.S., (1997). The Investigation of Utilization Possibility Rize-İyidere Agregates of Pit at The Concrete Product. Master Thesis, Gazi University, Ankara, 1-36 (in Turkish) .

[5] Poitevin, P., (1999). Limestone aggregate concrete, usefulness and durability. Cement and Concrete Composites, 21, 89-97.

[6] Tuğrul, E., (2015). The Investigation of Abrasion Resistance of Aggregates Under Different Conditions. Master Thesis, Firat University, Elazığ (in Turkish).

[7] Temiz, H., Binici, H., Bodur, M.N., and Kara, O., (2006). Engineering Properties of the Natural Aggregates in Kahramanmaraş. KSU Journal of Science and Engineering, 9(2), 6165 (in Turkish).

[8] Alyamaç, K.E. and Tuğrul, E., (2014). A Durable, Eco-Friendly and Aesthetic Concrete Work: Marble Concrete. In 11th International Congress on Advances in Civil Engineering (ACE 2014) (Vol:50, pp:21-25).

[9] Tuğrul, E., (2017). Investigation of Abrasion Resistance of Alacakaya Cherry Marble. 8th International Advanced Technologies Symposium, (4158-4166), 4012-4020.

[10] Tuğrul Tunç, E., (2018). Determination of Los Angeles Abrasion Loss of the Basalt Aggregate Type of Elazığ Province.

International Conference on Innovative Engineering Applications (CIEA-2018), (595-602).

[11] Postacıoğlu, B., (1987). Concrete (Aggregates, Concrete) Cilt II. Teknik Kitaplar Yayın Evi, İstanbul, 403 (in Turkish).

[12] Pul, S., (1994). Agrega Petrografik Yapısının Betonun Dayanım ve Akışkanlığı Üzerindeki Etkileri. Karadeniz Technical University, Master Thesis, Trabzon, 86s (in Turkish).

[13] Tunc, E.T., (2019). Recycling of marble waste: A review based on strength of concrete containing marble waste. Journal of environmental management, 231, 86-97, https://doi.org/10.1016/j.jenvman.2018.10.034.

[14] İpekoğlu, B., (1999). Quartz, Quartzite, Quartz Sand. İstanbul Maden İhracatçıları Birliği, Türkiye Endüstriyel Mineraller Envanteri, 102-106 (in Turkish).

[15] DPT Sekizinci Beş Yıllık Kalkınma Planı, (2001). Madencilik Özel Ihtisas Komisyonu Raporu. Endüstriyel Hammaddeler Alt Komisyonu, Toprak Sanayii Hammaddeleri III (Kuvars kumu, Kuvarsit, Kuvars) Çalışma Grubu Raporu, Devlet Planlama Teşkilatı, Ankara (in Turkish).

[16] Akçıl, A., Tuncuk, A., and Deveci, H., (2007). Kuvarsın Saflaştırılmasında Kullanılan Kimyasal Yöntemlerin İncelenmesi. Bilimsel Madencilik Dergisi, 46(4), 3-10 (in Turkish). 
[17] TS 802, (2016). Beton Karışım Tasarımı Hesap Esasları, Türk Standartları Enstitüsü, Ankara (in Turkish).

[18] TS EN 1097-2, 2010. Agregaların mekanik ve fiziksel özellikleri için deneyler, Türk Standartları Enstitüsü, Ankara (in Turkish).

[19] TS 706, (1981). Beton Agregaları. Türk standartları Enstitüsü, Ankara, (in Turkish).

[20] Temizel, K.E., (1998). Determination of Some Properties of Aggregates and Concrete Vvhich is Produced Using Those Aggregates from Kizilirmak River Basin, in Bafra Region, at Samsun. Master Thesis, Ondokuz Mayıs University, Samsun (in Turkish) .

[21] Yıldırım, M. and Yılmaz, I., (2002). Yıldız ırmağı çökellerinin beton agregası olarak kullanılabilirliklerinin incelenmesi, Cumhuriyet Üniversitesi Mühendislik Fakültesi Dergisi, 19(2), 181-192 (in Turkish).

[22] Sri Ravindrarajah, R. and Tam, C.T., (1985). Properties of Concrete made with Crushed Concrete As Coarse Aggregate. Magazine of concrete research, 37(130), 29-38.

[23] González-Fonteboa, B. and Martínez-Abella, F., (2008). Concretes with aggregates from demolition waste and silica fume. Materials and mechanical properties. Building and Environment, 43(4), 429437 .

[24] http://www.portalendustri.com 